\title{
Effectiveness of Online Learning System as a Supplemental Pedagogical Tool
}

\author{
Roseclaremath A. Caroro, Miraflor T. Jomuad, Jerry M. Lumasag \\ College of Computer Studies, Misamis University, Ozamiz City, Philippines \\ Corresponding email: claire130705@gmail.com
}

\begin{abstract}
Learning can be extended from the traditional face-to-face classroom experience towards the virtual pedagogical environment. This study evaluated the effectiveness of the Misamis University Online Learning Environment (MUOLE) established as a supplemental tool for classroom learning in all information technology and computer science subjects. A total of 342 students filled out the researcher-made questionnaire that served as the evaluation tool. Results showed that the students perceived the MU-OLE as an effective online learning system in downloading instructional materials and assignments, taking quizzes and examinations, submitting requirements, checking files and accessing scores from their secured personal account. It further showed that integrating online learning system with traditional teaching gives the students a great deal of convenience and ease in enhancing learning.
\end{abstract}

Keywords: content management system, evaluation, web-based learning, webbased tool 


\section{Introduction}

Learning can be extended from the traditional face-to-face encounter in the classroom towards the virtual environment. The use of the internet as a means for extending education and learning established new paradigms for learning (LaPointe \& Reisetter, 2008; Al-Dosari, 2011; Fasso, 2013). Web-based pedagogical tools aimed at strengthening the relationship between the teacher and students inside and outside of the classroom. The technology industries created dynamic websites to help facilitate online learning experiences using Moodle and other web-based learning technologies (Brooks-Young, 2008; McCall, 2009; Aranda, 2011; Blanco \& Ginovart, 2012; and Truelson, 2012; Fasso, 2013). Enriching face-to-face learning with supplemental web programs gained an advantage towards accomplishing students' activities utilizing the resources of the World Wide Web (Ng \& Nicholas, 2010)

The creation of web-based courses introduces a new aspect to pedagogy providing virtual learning spaces (Dawson, 2010). This learning introduces various technical advantages which include universal accessibility, ease in updating content, and hyperlink functions to facilitate cross-referencing other resources which allows more complex social interactions and designed learning experiences and encourage learners to be empowered through interactivity (De Freitas et al., 2010).

Web-based systems (Black, 2011), used by various organizations and academes, can be tools for information delivery that organizes the content of the information (Kim \& Moon, 2013) separately from the appearance of the information (Sireteanu et al., 2008). They allow teachers to manage their classes in an accessible online environment (Simonson, 2007). For example, computers and the internet provide modalities aiding in the delivery of planned instruction (Perreault et al., 2008). Virtual teaching and learning help facilitate individualized instruction (Cook 2007). Thus, now both virtual and face-to-face collaboration can be effective in achieving learning goals (Tutty \& Klein, 2007).

Several studies have been conducted to describe the role of webbased technologies in several aspects of the teaching-learning process. For example, one study described the belongingness that students experienced in an online learning community (Phelan, 2012) and awareness of the roles of others in on-line learning (Eneau \& Develotte, 2012). Performance of students in online learning contributed to higher levels of computer selfefficacy (Chou, 2013). Challenges addressed in online learning are those 
rooted from difficulties in communicating, misunderstanding of course goals, perceived lack of sense of community, study overload, and lack of technological skills (Koh \& Hill, 2009; Al-Dosari, 2011). Respondents, either students or teachers, reacted differently to online learning (Braun, 2008; Perreault et al., 2008; Tanner et al., 2009; Ng \& Nicholas, 2010; Castle \& McGuire, 2010; Power \& Vaughan, 2010; Gonzáles, 2012),

In addition, several studies have hinted that the use of online or web-based learning modalities requires some adjustments on its implementation and utilization on many areas such as learning experiences, interactivity, and assessment, among others (Dow, 2008; LaPointe \& Reisetter, 2008; Castle \& McGuire, 2010). In particular, the account management component has features that can effectively extend the respondents' account to their personal contacts and networks, thus giving them the chance to send and receive messages. In addition, the feature of allowing the students to send and receive private messages to/from other account owners is found effective. The feature allows the students to freely exchange messages with their classmates which is similar to a private chat room that they usually use in some social networking sites. The acceptance and use of the technology may influence and improve the learning process and learning outcome of the students (Sagarra \& Zapata, 2008; Al-Dosari, 2011; Baltes \& Nistor, 2011).

Based on the above mentioned advantages and challenges of webbased learning, the need to evaluate the Misamis University online learning environment is predicated with the fact that, since its establishment and use, no formal and periodic assessment or evaluation has been achieved. Hence, the present survey determined the students' perception on the effectiveness of the supplemental teaching pedagogy in the teaching and learning of the students in terms of the features, account management, the process of uploading assignments and activities, account security, and the overall use of the system.

The College of Computer Studies of Misamis University, Philippines, developed the supplemental on-line learning system named Misamis University - On-line Learning Environment (MU-OLE). It was established to supplement classroom learning in all information technology and computer science subjects. 


\section{Materials and Methods}

The study used the quantitative descriptive survey research method. A sample of 342 students $(\mathrm{N}=1,135)$ enrolled (first semester of the academic year 2012-2013) in information technology or computer science subjects served as respondents, to evaluate the effectiveness of the applied supplemental online learning system. A researcher-made and validated questionnaire served as the tool that comprised these areas: system's features, account management, uploading of assignments/activities, account security and the overall use of the system. The questionnaire consisted of statements with responses as follows: Strongly Agree - 4; Agree - 3; Disagree - 2; and, Strongly Disagree - 1 . It computed the Average Weighted Value (AWV) per item and interpreted per area of assessment as follows: (3.25 - 4.00) - Very Effective; (2.5 3.24) - Effective; (1.75 - 2.49) - Less Effective; and, (1.0-1.74) - Least Effective.

\section{Results and Discussion}

Table 1 presents the average weighted values on evaluating MUOLE's features. The respondents agree with the usefulness of MU-OLE as a supplemental medium of learning. It provides the respondents with a very effective procedure and ease in downloading files from the MU-OLE webpage as well as in logging into the site as these are the general tasks they do every time they use MU-OLE. Downloading and logging in tasks are easy for them in MU-OLE, considering that the procedures are the same, for example, with Youtube. Also, MU-OLE effectively provides a significant help to the students to be regularly updated with their activity scores and the teacher's feedbacks (De Freitas et al., 2010) regarding their outputs. It also provides significant help in coping up with missed lessons and submission deadlines, and reviewing instructional materials (Simonson, 2007), which are available in the MU-OLE.

The overall analysis reflects the features of MU-OLE that make the system effective as an instructional tool. Moreover, the results show that MU-OLE's feature effectively provides an advantage of allowing the students to take quizzes and examinations online. Students reported this as an advantage since taking the quiz can be made anytime and anywhere as long as it is within the deadline, which allows students who are not present in the class to take the online quiz or exam. 


\section{Table 1. Effectiveness of MU-OLE features}

\begin{tabular}{|c|c|c|c|}
\hline Statements & AWV & Interpretation & Rank \\
\hline $\begin{array}{l}\text { 1. Logging into the MU-OLE page for lessons, } \\
\text { notes, assignments, and quizzes is very easy. }\end{array}$ & 3.51 & $\begin{array}{l}\text { (Strongly Agree) } \\
\text { Very Effective }\end{array}$ & 2 \\
\hline $\begin{array}{l}\text { 2. Downloading files posted by the instructor is } \\
\text { convenient and helpful. }\end{array}$ & 3.59 & $\begin{array}{l}\text { (Strongly Agree) } \\
\text { Very Effective }\end{array}$ & 1 \\
\hline $\begin{array}{l}\text { 3. Checking for scores/grades for activities } \\
\text { completed or quizzes/exams taken is } \\
\text { accessible anytime. }\end{array}$ & 3.49 & $\begin{array}{l}\text { (Agree) } \\
\text { Effective }\end{array}$ & 3 \\
\hline $\begin{array}{l}\text { 4. Checking updates on lessons in the site, } \\
\text { whether in school or outside the campus is } \\
\text { applicable. }\end{array}$ & 3.41 & $\begin{array}{l}\text { (Agree) } \\
\text { Effective }\end{array}$ & 7 \\
\hline $\begin{array}{l}\text { 5. Taking quizzes and examinations through } \\
\text { online are an advantage. }\end{array}$ & 3.26 & $\begin{array}{l}\text { (Agree) } \\
\text { Effective }\end{array}$ & 10 \\
\hline 6. Lessons are accessible anytime. & 3.42 & $\begin{array}{l}\text { (Agree) } \\
\text { Effective }\end{array}$ & 5 \\
\hline 7. Accessing assignments is easy. & 3.38 & $\begin{array}{l}\text { (Agree) } \\
\text { Effective }\end{array}$ & 9 \\
\hline $\begin{array}{l}\text { 8. Online information helps students who were } \\
\text { absent from class. }\end{array}$ & 3.41 & $\begin{array}{l}\text { (Agree) } \\
\text { Effective }\end{array}$ & 7 \\
\hline $\begin{array}{l}\text { 9. Re-submission of activities can be } \\
\text { facilitated, if allowed by the instructor. }\end{array}$ & 3.42 & $\begin{array}{l}\text { (Agree) } \\
\text { Effective }\end{array}$ & 5 \\
\hline $\begin{array}{l}\text { 10. Teacher's feedbacks on the activities } \\
\text { submitted are viewable. }\end{array}$ & 3.45 & $\begin{array}{l}\text { (Agree) } \\
\text { Effective }\end{array}$ & 4 \\
\hline Overall Average Weighted Value & 3.43 & Effective & \\
\hline
\end{tabular}

Table 2 presents the weighted mean on evaluating MU-OLE's account management. The respondents strongly agree on the ease and convenience of managing their accounts in the system indicating a very effective means of adding their contacts and links to their accounts.

Results show that MU-OLE highly provides the respondents with a very effective process of using the primary account management. This includes the logging in and out of the webpage and the changing of passwords and updating of profile information. MU-OLE provides an introductory topic on using the MU-OLE to students. The students already have their own accounts in any of the websites especially in social networking sites and emails. This makes them very familiar with the basic tasks of getting into their account. 
Table 2. Effectiveness of MU-OLE account management.

\begin{tabular}{lllll}
\hline \hline Statements & AWV & Interpretation & Rank \\
\hline 1. Account owners can edit their profile. & 3.56 & $\begin{array}{l}\text { (Strongly Agree) } \\
\text { Very Effective } \\
\text { (Strongly Agree) }\end{array}$ & 3 \\
2. Account owners can change their & 3.63 & $\begin{array}{l}\text { Very Effective } \\
\text { (Strongly Agree) }\end{array}$ & 1.5 \\
$\begin{array}{l}\text { password. } \\
\text { Login and log out features are } \\
\text { understandable. }\end{array}$ & 3.63 & $\begin{array}{l}\text { (Agree) } \\
\text { Effective } \\
\text { (Agree) }\end{array}$ & 4 \\
$\begin{array}{l}\text { Account owners can link their MU-OLE } \\
\text { account to their personal email address. }\end{array}$ & 3.46 & 5 \\
$\begin{array}{l}\text { Account owners can add contacts to their } \\
\text { account. }\end{array}$ & 3.36 & $\begin{array}{l}\text { (Agree) } \\
\text { Account owners can send and receive } \\
\text { private messages to/from other account } \\
\text { owners. }\end{array}$ & 3.35 & 6 \\
Overall Average Weighted Value & 3.50 & Very Effective & \\
\hline \hline
\end{tabular}

Table 3 presents the analysis of the responses on evaluating MUOLE's capability of uploading assignments or activities given by the teacher. The respondents agree that the use of this capability is effective, and gives them confidence that they will meet the requirements' deadlines and secure their submitted class requirements.

Considering MU-OLE's capability of uploading assignments and activities, the evaluation shows that it is a very effective way of securing the requirements submitted by the students since the system displays the uploaded file along with the activity instructions posted. Submissions can also be confirmed in the instructor's account by viewing on the checklist the students who have submitted the requirements and those who have not. It also displays the details of the submitted requirements like the date and time of upload. Results further show that the system effectively provides the students reminders on deadlines through regularly displaying them whenever there are activities/tasks to be submitted.

With this capability available in the system, students who were not able to attend classes for valid reasons can still make up with the assignments/tasks and can still submit them. With the valid reasons for an absence as may be determined by the instructors, the students will have the chances of seeing the requirements/tasks online, thus can still comply with the required learning outcomes for the lesson. In addition, MU-OLE effectively implements the maximum allowable byte size for file uploads. This feature facilitates faster and complete file upload since the file has a smaller byte size. Hence, the feature prevents possibilities of file 
corruption and network congestion whenever the students simultaneously upload their outputs to the online system.

\section{Table 3. Effectiveness of MU-OLE's capability of uploading assignments/activities.}

\begin{tabular}{|c|c|c|c|}
\hline Statements & AWV & Interpretation & Rank \\
\hline $\begin{array}{l}\text { 1. Account owners can upload files of } \\
\text { different types. }\end{array}$ & 3.41 & $\begin{array}{l}\text { (Agree) } \\
\text { Effective }\end{array}$ & 2 \\
\hline $\begin{array}{l}\text { 2. Account owners can check whether their } \\
\text { files are uploaded. }\end{array}$ & 3.63 & $\begin{array}{l}\text { (Strongly Agree) } \\
\text { Very Effective }\end{array}$ & 1 \\
\hline $\begin{array}{l}\text { 3. There is a restriction on the maximum } \\
\text { size of the files to be uploaded in MU- } \\
\text { OLE. }\end{array}$ & 3.31 & $\begin{array}{l}\text { (Agree) } \\
\text { Effective }\end{array}$ & 4 \\
\hline $\begin{array}{l}\text { 4. Deadlines for assignment and time limits } \\
\text { for quizzes/examinations are always } \\
\text { displayed on the screen for the students } \\
\text { to be constantly reminded. }\end{array}$ & 3.39 & $\begin{array}{l}\text { (Agree) } \\
\text { Effective }\end{array}$ & 3 \\
\hline Overall Average Weighted Value & 3.44 & Effective & \\
\hline
\end{tabular}

Table 4 presents the average value of the responses in evaluating MU-OLE's account security. The respondents agree that MU-OLE effectively provides a reliable account security features, though these features are the primary ones. Regarding the MU-OLE's account security, results revealed that it can effectively secure the students' account and their classroom performance information, considering that they are the only ones who can log in and view their account and to keep their account safe; they can change their password any time as there are no restrictions as to how many allowable password changes can be made. Although the students failed to connect their MU-OLE account to their personal email addresses, they can still have their new passwords, whenever they forget, through the systems administrator of the MU-OLE. In addition, MU-OLE provides a feature that allows only the instructor to enrol the students in his class to the online system to prevent other students to spy any task/activity. Furthermore, the system effectively allows only the teacher to officially enrol the students in the online system. This feature limits only the officially enrolled student of a particular class to be enrolled in the online class to avoid eavesdropping or spying on the activities given for the students to comply or submit. 
Table 4. Effectiveness of MU-OLE account security.

\begin{tabular}{|c|c|c|c|}
\hline Statements & AWV & Interpretation & Rank \\
\hline $\begin{array}{l}\text { 1. Account owners can change their } \\
\text { password from time to time. }\end{array}$ & 3.39 & $\begin{array}{l}\text { (Agree) } \\
\text { Effective }\end{array}$ & 2 \\
\hline $\begin{array}{l}\text { 2. Lost or forgotten password can be } \\
\text { replaced with new one through the } \\
\text { students, personal email account, if } \\
\text { linked to MU-OLE, or through manual } \\
\text { reset function performed by the System } \\
\text { Administrator of MU-OLE, for account } \\
\text { security. }\end{array}$ & 3.33 & $\begin{array}{l}\text { (Agree) } \\
\text { Effective }\end{array}$ & 3 \\
\hline $\begin{array}{l}\text { 3. Only the account owner can view his } \\
\text { scores on quiz, exercises and other } \\
\text { laboratory activities. }\end{array}$ & 3.48 & $\begin{array}{l}\text { (Agree) } \\
\text { Effective }\end{array}$ & 1 \\
\hline $\begin{array}{l}\text { 4. A feature of limiting the enrollment } \\
\text { process, to be done by the teacher, to } \\
\text { enroll his students to his subject is } \\
\text { available. This is students to be } \\
\text { officially enrolled in the system. }\end{array}$ & 3.16 & $\begin{array}{l}\text { (Agree) } \\
\text { Effective }\end{array}$ & 4 \\
\hline Overall Average Weighted Value & 3.34 & Effective & \\
\hline
\end{tabular}

Table 5 presents the average weighted value on assessing the use of MU-OLE as a whole system. Results show that MU-OLE as a system still effectively helps the students enhance learning than using the traditional learning alone, despite some less effective responses on its use. This finding reflects what other online learning experts suggested that online learning must still provide students clear guidelines relevant to their learning-related experiences (Brooks-Young, 2008; McCall, 2009; Aranda, 2011; Blanco \& Ginovart, 2012; Truelson, 2012).

The feature also includes the provision of not allowing the students to resubmit their work outputs. It also includes the provision of preventing late submissions. The system also provides cautions and time limit to students when taking a timed exam or quiz, to finish them before the time runs out. Results indicate that the system will effectively make the students become independent, especially with a feature on randomly generating online quiz or examination questions and displayed by the system, different from one student to another. Hence, the MU-OLE reflects the concept that web-based learning approaches effectively supplement the classroom learning ( $\mathrm{Ng} \&$ Nicholas, 2010).

Caution, however, should be undertaken as free access to various learning materials and assignments in the system which students can study and undertake by themselves. On the other hand, the on-line tool enables 
students to exchange freely ideas among themselves without the teacher's facilitation, on activities, quizzes and assignments beyond class hours. The system is less effective in not allowing students to copy the work of others as compared to face-to-face teaching. Thus, it is now the discretion of the instructor on how he will treat similar answers as it displays the details of uploaded file that include the session of uploading and the byte size of the file.

In as much as students showed greater likelihood to use the online tool in consonance with what others students revealed in several studies (Sagarra \& Zapata, 2008; Al-Dosari, 2011; Baltes \& Nistor, 2011), instructors need to consider strategies to motivate students to attend faceto-face classroom sessions while they also work independently on online activities beyond class hours. Other online learning practitioners implemented those strategies especially in settings where blended learning is applied (Dow, 2008; LaPointe \& Reisetter, 2008; Castle \& McGuire, 2010). It should be noted that, in this study, students indicated that the MU-OLE is not effective to replace the typical classroom setting. Students still prefer to attend regular classes and comply with directed tasks described in online classes. Hence, students consider only the MU-OLE as a tool to supplement the typical classroom learning.

Table 5. Effectiveness of MU-OLE as a whole system.

\begin{tabular}{|c|c|c|c|}
\hline Statements & AWV & Interpretation & "Rank \\
\hline $\begin{array}{l}\text { 1. MU-OLE can replace the typical classroom } \\
\text { setting. }\end{array}$ & 1.78 & $\begin{array}{l}\text { Disagree } \\
\text { (Less Effective) }\end{array}$ & 7 \\
\hline $\begin{array}{l}\text { 2. Deadlines on requirements are clearly } \\
\text { displayed and imposed. }\end{array}$ & 3.27 & $\begin{array}{l}\text { Agree } \\
\text { (Effective) }\end{array}$ & 1 \\
\hline $\begin{array}{l}\text { 3. MU-OLE will not make the students lazy in } \\
\text { attending classes. }\end{array}$ & 2.37 & $\begin{array}{l}\text { Disagree } \\
\text { (Less Effective) }\end{array}$ & 6 \\
\hline $\begin{array}{l}\text { 4. It will make the students become } \\
\text { independent. }\end{array}$ & 2.96 & $\begin{array}{l}\text { Agree } \\
\text { (Effective) }\end{array}$ & 4 \\
\hline $\begin{array}{l}\text { 5. It will not allow students to copy the work of } \\
\text { others. }\end{array}$ & 2.44 & $\begin{array}{l}\text { Disagree } \\
\text { (Less Effective) }\end{array}$ & 5 \\
\hline $\begin{array}{l}\text { 6. Online quizzes or exams have imposed time } \\
\text { limits. }\end{array}$ & 3.08 & $\begin{array}{l}\text { Agree } \\
\text { (Effective) }\end{array}$ & 2 \\
\hline $\begin{array}{l}\text { 7. Online quiz or exam questions are randomly } \\
\text { generated and displayed by the system, } \\
\text { different from one student to another. }\end{array}$ & 3.04 & $\begin{array}{l}\text { Agree } \\
\text { (Effective) }\end{array}$ & 3 \\
\hline Overall Average Weighted Value & 2.71 & Effective & \\
\hline
\end{tabular}


Table 6 presents the summary of the effectiveness of MU-OLE as a supplemental pedagogical tool. Data show that the MU-OLE effectively contributes to the learning of the students by using it as a supplemental tool. This is evident in the students' ratings of its features, account management system, capability of uploading assignments and activities, and account security. Although some aspects of MU-OLE are viewed as less effective, the technology in its overall aspects has been considered an effective supplemental tool for learning.

Table 6. Summary of the effectiveness of MU-OLE as a supplemental pedagogical tool.

\begin{tabular}{|c|c|c|c|}
\hline Statements & AWV & Interpretation & Rank \\
\hline 1. Effectiveness of MU-OLE features & 3.43 & Effective & 3 \\
\hline $\begin{array}{l}\text { 2. Effectiveness of MU-OLE account } \\
\text { management }\end{array}$ & 3.50 & Very Effective & 1 \\
\hline $\begin{array}{l}\text { 3. Effectiveness of MU-OLE's capability of } \\
\text { uploading assignments/activities }\end{array}$ & 3.44 & Effective & 2 \\
\hline 4. Effectiveness of MU-OLE account security & 3.34 & Effective & 4 \\
\hline 5. Effectiveness of MU-OLE as a whole system & 2.71 & Effective & 5 \\
\hline Overall Average Weighted Value & 3.28 & Effective & \\
\hline
\end{tabular}

\section{Conclusion and Recommendations}

Based on the findings of this evaluation, the MU-OLE has effectively served as a supplemental tool for teaching and learning among students and teachers. Teachers may consider strategies in delivering lessons and activities without compromising the students' attendance and behavior in classes. MU-OLE is less effective in monitoring the students who intentionally copy other students' work. The system opens for possibilities that students develop the behavior of copying the work of others when they are working online. Teachers need to strategize to effectively and efficiently monitor students' outputs to avoid students' tendency to plagiarize. The teachers have to develop classroom policies to maintain students' perfect attendance in both the traditional classroom and online settings. 


\section{Acknowledgment}

The authors are thankful to Misamis University for providing the financial support. The researchers are also grateful to the laboratory personnel in the College of Computer Studies for their technical support.

\section{Literature Cited}

Al-Dosari, H. (2011). Faculty members and students perceptions of Elearning in the english department: A project evaluation. Journal of Social Sciences, 7(3), 291-407.

Aranda, A. D. (2011). Moodle for distance education. Distance Learning, $8(2), 25-28$.

Baltes, B., \& Nistor, N. (2011). Virtual mentoring in communities of practice in an online university: Technology acceptance, technology use, and perceptions of the learning process. International Journal of Arts \& Sciences, 4(16), 337-346.

Black, E. P. (2011). Selecting a web content management system for an academic library website. Information Technology and Libraries, 30(4), $185-189$.

Blanco, M., \& Ginovart, M. (2012). On how moodle quizzes can contribute to the formative E-assessment of first-year engineering students in mathematics courses. RUSC, 9(1), $354-370$.

Braun, T. (2008). Making a choice: The perceptions and attitudes of online graduate students. Journal of Technology and Teacher Education, 16(1), 63-92.

Brooks-Young, S. (2008). Got moodle? T.H.E. Journal, 35(4), 28-28, 30.

Castle, S. R., \& McGuire, C. J. (2010). An analysis of student selfassessment of online, blended and face-to-face learning environments: Implications for sustainable education delivery. International Education Studies, 3(3), 36 - 40. 
Chou, P. (2013). Students' perceptions of success in the online graduatelevel classes: A self-directed learning perspective. Contemporary Issues in Education Research (CIER), 6(1), 115-122.

Cook, D. A. (2007). Web-based learning: pros, cons and controversies. Clinical Medicine, 7(1), 37 - 42.

Dawson, S. (2010). 'Seeing' the learning community: An exploration of the development of a resource for monitoring online student networking. British Journal of Educational Technology, 41(5), 736 752.

De Freitas, S., Rebolledo-Mendex, G., Liarokapis, F., Magoulas, G., \& Poulovassilis, A. (2010). Learning as immersive experiences: Using the four-dimensional framework for designing and evaluating immersive learning experiences in a virtual world. British Journal of Educational Technology, 41(1), 69 - 85.

Dow, M. J. (2008). Implications of social presence for online learning: A case study of MLS students. Journal of Education for Library and Information Science, 231-242.

Eneau, J., \& Develotte, C. (2012). Working together online to enhance learner autonomy: Analysis of learners' perceptions of their online learning experience. ReCALL: The Journal of EUROCALL, 24(1), 3 19.

Fasso, W. (2013). First year distance transition pedagogy: Synchronous online classrooms. The International Journal of the First Year in Higher Education, 4(1), 33 - 45.

Kim, K. R., \& Moon, N. M. (2013). Designing a social learning content management system based on learning objects. Multimedia Tools and Applications, 64(2), $423-437$.

Gonzáles, C. (2012). The Relationships between approaches to teaching, approaches to E-teaching and perceptions of the teaching situation in relation to E-learning among higher education teachers. Instructional Science, 40(6), 975-998. 
Koh, M. H., \& Hill, J. R. (2009). Student perceptions of groupwork in an online course: Benefits and challenges. The Journal of Distance Education/Revue de l'Éducation à Distance, 23(2), 69-92.

LaPointe, L., \& Reisetter, M. (2008). Belonging online: Students' perceptions of the value and efficacy of an online learning community. International Journal on E-Learning, 7(4), 641-665.

McCall, M. (2009). It's ok to moodle at School. Principal Leadership, $9(5), 62-63$.

Ng, W., \& Nicholas, H. (2010). A progressive pedagogy for online learning with high-ability secondary school students: A case study. Gifted Child Quarterly, 54(3), 239-251.

Perreault, H., Waldman, L., Alexander, M., \& Zhao, J. (2008). Graduate business students' perceptions of online learning: A five year comparison. Delta Pi Epsilon Journal, 50(3), 164 - 179.

Phelan, L. (2012). Interrogating students' perceptions of their online learning experiences with Brookfield's critical incident questionnaire. Distance Education, 33(1), 31 - 44.

Power, M., \& Vaughan, N. (2010). Redesigning online learning for international graduate seminar delivery. Journal of Distance Education, 24(2), 19-38.

Sagarra, N., \& Zapata, G. C. (2008). Blending classroom instruction with online homework: A study of student perceptions of computer-assisted L2 learning. ReCALL: The Journal of EUROCALL, 20(2), 208-224.

Simonson, M. (2007). Course management systems. Quarterly Review of Distance Education, 8(1), 7 - 9. 
Sireteanu, N. A., Dinu, A., Andone, I., \& Homocianu, D. (2008). Implementing a web content management system for an educational institution. In The 3rd International Conference "Knowledge Management-Projects, Systems and Technologies", Bucharest, Romania, $23-25$.

Tanner, J. R., Noser, T. C., \& Totaro, M. W. (2009). Business faculty and undergraduate students' perceptions of online learning: A comparative study. Journal of Information Systems Education, 20(1), 29-40.

Truelson, S. (2012). Moodle: A distinct solution to online learning. Distance Learning, 9(1), 43 - 48.

Tutty, J. I., \& Klein, J. D. (2007). Computer-mediated instruction: A comparison of online and face-to-face collaboration. Educational Technology Research and Development, 56(2), $101-124$. 